\title{
Cost Calculation of Building Structures and Building Works in Polish Conditions
}

\author{
Agnieszka Leśniak ${ }^{1}$, Edyta Plebankiewicz ${ }^{1} \&$ Krzysztof Zima ${ }^{1}$ \\ ${ }^{1}$ Section of Technology and Building Management, Cracow University of Technology, Cracow, Poland \\ Correspondence: Edyta Plebankiewicz, Section of Technology and Building Management, Cracow University of \\ Technology, Warszawska 24, 31-155 Cracow, Poland. E-mail: eplebank@izwbit.pk.edu.pl
}

Received: June 7, 2012 Accepted: July 17, 2012 Online Published: October 26, 2012

doi:10.5539/emr.v1n2p72 URL: http://dx.doi.org/10.5539/emr.v1n2p72

\begin{abstract}
Cost analyses for building structures are developed at all stages of the investment process. The paper describes the basic forms of cost calculation of building structures and building works applied in Poland. The most frequently used sources of price information for this purpose are presented herein. The examples provided, show differences in the cost of building works calculated based on data provided by different price publishing. The paper strives to identify the causes of price differences arising at each stage of cost calculation, and provides the solutions of cost reduction.
\end{abstract}

Keywords: cost of building works, price information, price publishing

\section{Introduction}

Planning of the construction project is a multi-stage operation. Practically at every stage, from the idea of the project up to its full settlement, cost analyses are carried out (Dziadosz \& Zima, 2011). The references show a number of methods which aim to determine the cost as effectively as possible, which is particularly complicated at the planning stage (Ciraci \& Polat, 2009; Akintoye, 2000; Oberlender \& Trost, 2001). The further the stage of the investment process the more data and information that allow for more accurate and precise determination of costs can be obtained. In different countries different rules and sources of information were developed to help clients and contractors determine the costs of works (Peterson \& Dagostino, 2011; Van Kempen, 1983; Holm et al., 2004).

Some authors (Hegazy \& Ayed, 1998; Arafa \& Alqedra, 2011; Petroutsatou et al., 2012); developed a neural network model for an early stage of cost estimation in construction business. In his research (Kim et al., 2005) applied hybrid models of neural network and genetic algorithms to an early stage of cost estimation of residential buildings to predict preliminary cost estimates.

The authors already mentioned (Oberlender \& Trost, 2001) concentrated more on improving prediction accuracy by deriving four determinants influencing the accuracy of early cost estimates. The authors established a multiple regression model in which the relationship between estimate accuracy and several factors, such as basic process design, site requirements, team experience, cost information and time, allowed to prepare an estimated market situation.

It is understood that estimating accurately construction costs during the initial stage of the project is essential. This is achieved by, for instance, a very interesting model of cost estimation employing case-based reasoning (CBR) in cost prediction models (Ji et al., 2010).

The paper focuses on the cost estimates made in the Polish market regarding investment works, which involve the construction of buildings. The article presents basic steps, at which the cost of works is calculated and the most frequently used sources of price information. The examples show differences in the cost of building works produced at different stages of the investment process. The aim of the article is to present the differences in the calculated costs at the subsequent stages of the investment process, to identify the causes of the costs and to suggest the possibilities of their reduction.

\section{Cost Analysis at the Conceptual Stage}

Estimating the size of capital expenditure is the key task in the initial phase of the investment process, i.e. a conceptual stage. At an early stage the client has merely a general concept of the project described in a form of a 
functional and utility program or a conceptual design. Studies regarding costs performed on the basis of only general information must therefore be characterized by considerable price dispersion. For the client's needs cost estimates are prepared and designed to give an approximate, estimated total cost of the construction project. The calculated cost, usually based on the indicators is only an approximate value, additionally burdened with a large "blurriness" of results. A large range of variations in estimates is due to lack of detailed information concerning the proposed project and associated cost calculation methods. Cost estimation methods applied by the quantity surveyor and price bases also significantly affect the result of the calculation.

Estimation methods, which can be applied by the Quantity Surveyor, are as follows:

- cost estimation method based on usable area of the building,

- cost estimation method based on the volume of the building,

- cost estimation method based on the unit price of integrated items and aggregate works.

Price bases published in Poland and used in estimating by means of these methods are presented in Table 1 (Zima, 2011).

Table 1. Examples of Polish price bases used in estimations of construction costs of buildings at the conceptual stage

\begin{tabular}{|c|c|c|c|}
\hline & \multicolumn{3}{|c|}{ Cost estimating method } \\
\hline Publishing & $\begin{array}{c}\text { cost estimation method } \\
\text { based on usable area of the } \\
\text { building }\end{array}$ & $\begin{array}{l}\text { cost estimation method based } \\
\text { on the volume of the building }\end{array}$ & $\begin{array}{l}\text { cost estimation method based } \\
\text { on the unit price of } \\
\text { integrated items and } \\
\text { aggregate works }\end{array}$ \\
\hline $\begin{array}{c}\text { Oweob } \\
\text { Promocja - } \\
\text { Sekocenbud }\end{array}$ & $\begin{array}{l}\text { Structures prices bulletin - } \\
\text { BCO (part I - buildings } \\
\text { and part II - civil } \\
\text { structures) } \\
\text { Estimated value of projects } \\
\text { - price indices }\end{array}$ & $\begin{array}{l}\text { Structures prices bulletin - } \\
\text { BCO (part I - buildings and } \\
\text { part II - civil structures) } \\
\text { Estimated value of projects - } \\
\text { price indices }\end{array}$ & $\begin{array}{l}\text { Structures prices bulletin - } \\
\text { BCO (part I - buildings and } \\
\text { part II - civil structures) } \\
\text { Works range prices bulletin - } \\
\text { BCA }\end{array}$ \\
\hline $\begin{array}{c}\text { Bistyp } \\
\text {-Consulting }\end{array}$ & $\begin{array}{l}\text { Unit price catalogue of } \\
\text { works and structures }\end{array}$ & $\begin{array}{l}\text { Unit price catalogue of works } \\
\text { and structures }\end{array}$ & $\begin{array}{l}\text { Unit price catalogue of } \\
\text { works and structures }\end{array}$ \\
\hline Wacetob & $\begin{array}{c}\text { Merged norms for } \\
\text { valuation of buildings and } \\
\text { structures }\end{array}$ & $\begin{array}{l}\text { Merged norms for valuation of } \\
\text { buildings and structures }\end{array}$ & $\begin{array}{c}\text { Merged norms for valuation } \\
\text { of buildings and structures } \\
\text { Valuation of buildings - } \\
\text { database to the replacement } \\
\text { method }\end{array}$ \\
\hline Orgbud Serwis & & & $\begin{array}{l}\text { ICAR - Information list of } \\
\text { average prices of } \\
\text { construction and installation } \\
\text { works range } \\
\text { IWNB - Information list of } \\
\text { expenditure indices of } \\
\text { building structures }\end{array}$ \\
\hline
\end{tabular}

\section{Estimating the Value of Construction Works Contract}

Construction works can be delivered in two primary forms. The first one is the traditional system, where the client separates the execution of design works from construction works (the so-called Design-Bid-Build system). 
The second way is the Design \& Build system, where one contractor is contracted both the execution of design works and construction works. The Public Procurement Law applicable on the public procurement market in Poland, defines in Article 2 that the works contract shall mean the execution or the design and execution of works within the meaning of the Act of 7 July 1994 - Construction Law. Accordingly, the client can carry out public projects by means of two methods: Design-Bid-Build or Design \& Build. In the first one, the client will be obliged to award two separate contracts: a service contract for development of documentation and a contract for construction works. In this case, the object of the contract is described by means of design documentation and technical specifications for implementation and delivery of works, whilst the contract value is determined based on the client's cost estimate. In the second one, a single contract includes both delivery of design works and construction works. Then the client does not yet have the design documentation, and the value of such contract shall be determined on the basis of estimated costs of design works and estimated costs of construction as specified in the functional and utility programme.

Detailed rules of preparation of these two cost studies are provided for in the Regulation of the Minister of Infrastructure dated 18 May 2004 on determining the method and basis of preparation of a client's cost estimate, calculation of expected costs of design and expected costs of construction specified in the functional and utility programme.

These studies play an important role in public procurement. They provide, among others:

- determination of the amount that would be spent by the client on financing the contract,

- classification of a contract to the appropriate threshold range, which enables the selection of an appropriate procedure for awarding contracts and compliance with the requirements of the PPL, depending on the value of the contract (e.g. the content of Terms of Reference, the amount of a tender bond, publication of notices, etc.)

- assessment of the completeness and review of technical data of the cost estimate: design documentation and technical specifications for implementation and delivery of works,

- assessment of price offers submitted by contractors, applying for carrying out the works.

Pursuant to the Regulation of the Minister of Infrastructure dated 18 May 2004, the client's cost estimate is developed by means of a simplified calculation method, consisting in the calculation of the estimate value of works included in the Bill of Quantities as the sum of products of the numbers of BQ items of basic works and their unit prices less value added tax.

In determining the unit prices of works, the following should be used in order:

- unit prices of works determined on the basis of commercial data, including data from the previously concluded agreements or widely used up-to-date publication,

- detailed calculations.

Table 2 shows examples of publications where one can find prices of construction works.

Table 2. Sample publications containing unit prices of construction works

\begin{tabular}{ll}
\hline Publishing & \multicolumn{1}{c}{ Name } \\
\hline Athenasoft & Catalogue of unit prices of works - INTERCENBUD \\
Oweob Promocja - Sekocenbud & Bulletin of prices of road and bridge works \\
Orgbud-Serwis & Prices of the Project Construction Works \\
& Prices of the Project Installation Works Prices of Renovation \\
& Construction Works \\
Oweob Promocja - Sekocenbud & Bulletin of prices of the Project Construction Works
\end{tabular}

Bistyp-Consulting.

Catalogue of the PROJECT unit prices of works and structures

The estimated value of construction works, consisting in design and execution, is the sum of the value of expected costs of construction works and planned costs of design works. 
The expected costs of works shall be calculated by means of an indicator-based method, as the sum of products of price indices of individual components of the cost and the number of their units. The individual cost components are determined taking into account the classification of the Common Procurement Vocabulary, whereas the distribution of these costs should at least correspond with groups of works within the meaning of the vocabulary (CPV). These are the following groups of costs:

- Group 1 - the cost of site preparation works (code 45100000),

- Group 2 - the cost of the works of construction of basic facilities (code 45200000),

- Group 3 - the cost of installation works (code 45300000),

- Group 4 - the cost of building completion works (code 45400000),

- Group 5 - the cost of land development and construction of auxiliary facilities (code 45500000).

Price indices for individual cost components are determined on the basis of market data or on the basis of widely used catalogues and price lists, whist the reference unit number is determined based on a functional and utility programme. In the absence of indicators in the available publications, they can be calculated in the individual budget, using information from concluded agreements, or contracts or tenders, taking into account the forecasts. The valuation can apply publications on prices of works and structures mentioned in earlier chapters.

Expected costs of design work are calculated by multiplying the percentage index and expected costs of works. For example - the percentages of the design of construction and installation of buildings range from $2.25 \%$ to $9.4 \%$ of the estimated cost of works. In general, the selection of appropriate indicator depends on the value of expected costs of construction and complexity of the project.

\section{Calculation of Tender Price}

Delivery of a construction project is usually preceded by the preparation of tender cost estimates, which in the case of a lump-sum settlement determines the remuneration of the contractor, whilst in the case of cost estimation is the basis for settlement of accounts. Correct preparation of tender cost estimate requires a thorough analysis of a technical and formal and legal documentation, as well as the adoption of appropriate price setting data and overhead.

Tender cost estimate is performed, as mentioned earlier, by adopting a method of simplified or detailed calculation (Plebankiewicz, 2007). Detailed calculation consists in calculating the estimate price of a structure or works by multiplying: a number of fixed BQ items, unit pricing, and their prices plus appropriate indirect costs and margin, including VAT - according to the following formula:

$$
C k=\sum L *(n * c+K p j+Z j)+P v
$$

or

$$
C k=\sum(L * n * c)+K p+Z+P v
$$

where:

$C k$ - estimated price,

$L$ - number of fixed BQ items,

$n$ - unit pricing of: labour $-n_{r}$, materials $-n_{m}$, labour of machinery and service vehicles $-n_{s}$,

$c$ - unit prices of production factors, including: estimate hourly labour rate $-c_{r}$, unit prices of materials $-c_{m n}$, unit prices of hourly work of machinery and service vehicles $-c_{s}$,

$n * c$-direct costs as per BQ item calculated by the formula:

$n * c=n_{r} c_{r}+\sum n_{m} c_{m n}+M_{p j}+\sum n_{s} c_{s}$

$M_{p j}$ - costs of auxiliary materials as per BQ item,

$K p j-$ indirect costs as per BQ items,

$K p$ - indirect costs,

$Z j-$ calculated profit as per BQ item,

$Z$ - calculated profit,

$P v-\mathrm{VAT}$ 
To estimate a tender price through the detailed calculation method it is necessary to adopt unit prices of labour, materials and machinery. Prices of production factors are determined on the following bases:

- client's or contractor's own calculations,

- market data or published information on the prices of production factors,

- bilateral arrangements.

Among the pricing guide-books that are applied for the purpose of a specific cost valuation, the following may be used:

ICCP - Prices of Construction Production Factors, publisher: ORGBUD-SERWIS,

BCB - Bulletin of Construction Works Prices, pub.: ORGBUD-SERWIS

Błyskawica ("Lightning") - Information on prices of the main production factors, pub.: OWEOB PROMOCJA SEKOCENBUD,

IMB - Information on Building Materials Prices, pub.: OWEOB PROMOCJA - SEKOCENBUD,

IRS - Information on Estimate Labour Rates and Building Equipment Working Rates, pub.: OWEOB PROMOCJA - SEKOCENBUD,

Internet Database of Material Prices INTERCENBUD, pub.: Athenasoft,

Bulletin of Building Materials Pricelist, pub.: BISTYP-CONSULTING,

Pricelist of building equipment hire, pub.: BISTYP-CONSULTING.

\section{Forecast versus Actual Costs of Building Works}

The problems with cost calculation in Poland are: a low quality of technical documentation, short deadline for submission of tenders, frequent changes in the scope and quantity of works, which cause significant discrepancy between the tender cost estimate and the actual cost of works. A progress in technology of works performance, the influx of new building materials and equipment, results in the situation where in the period between the development of the design of a specific structure or work, and its submission for implementation and execution, both parties agree to perform works by applying another technology, or using other materials as compared to those proposed in the design.

Differences between the client's cost estimate, tender cost estimate, and the actual costs are common and practically impossible to avoid. It is important however, to seek to minimize them, by properly forecasting the construction costs.

The influence of the calculation on the actual gain of the contractor is determined by the adopted form of remuneration. In Poland there are two basic ways of settlement of works specified in the Civil Code. The parties may accept either a cost estimate or a lump sum payment pursuant to the Civil Code, but according to the principle of freedom of contract they may accept other forms of remuneration. In Poland, the most popular is a lump sum settlement (fixed price), however, if unable to determine the scope or amount of works, the parties are forced to settlement by cost estimation (according to the actual quantity of works). Very rarely, there are other forms of payment such as the target cost, where the parties share the risk among them as agreed.

In a lump sum payment the contractor is paid a pre-determined amount of money. According to art. 632, par.1 of the Civil on lump sum payments, a party accepting the contract in Poland cannot demand an increase of payment even if at the time of concluding the contract agreement it was not possible to predict the scope or cost of works. The Civil Code, under article. 632, par.1 allows a change of a fixed price, but only under the court proceedings and provided the following requirements are met:

- there must be a change in the relations, which could not have been foreseen,

- delivery of the work would result in a gross loss to the client.

In the case of a lump sum settlement the differences between forecast and actual costs are covered by the contractor, so it is particularly important to carefully plan the costs and consider the risk that may be associated with their change. In the case of cost estimation it is the client who takes the risk of any increase of the budget and the need to obtain additional financial resources (Dolecki, 2010).

\section{Cost Variability Analysis}

A multi-family 3-storey building, erected in the traditional method in Poland, was subject to cost analysis. Raw (base) stage and building shell costs of the building are shown in Fig. 1. Cost estimates were calculated at 
different stages of the construction project life-cycle, from the cost estimate at the conceptual stage, to the stage of the contractor selection. The assumed pricing level is the $4^{\text {th }}$ quarter of 2011 . Cost estimation of the conceptual stage was carried out based on the publication by Promocja Sp. z o.o.: Sekocenbud WKI - Estimated Project Value. The cost range was assumed as in the published scope of minimum and maximum costs for structure no. 3.122.21.

The second cost estimate concerned the cost estimate of the designed integrated items of the structure, taking into consideration two options of the specific integrated items solutions. The estimate was based on the pricelist provided by Promocja Sp. z o.o.: Sekocenbud BCO (Bulletin of Costs of Structures), structures no. 1112 and 1121. In this manner the minimum and maximum values were obtained.

The following approximation of the raw stage and building shell costs was performed after the completion of the building design, already based on unit prices of works or building items (Promocja Sp. z o.o.: Sekocenbud BCJ Bulletin of Unit Prices). The last cost valuation was the client's estimate, prepared by the authors of this paper on the basis of the maximum and minimum prices found in the pricelists of Promocja Sp. z o.o. Sekocenbud RMS (RMS - Prices of Labour, Materials and Machinery). The authors of this paper also developed an alternative tender cost estimate based on the market prices which shows the negotiating options from the contractor's perspective. The obtained results are shown in Figure 1.

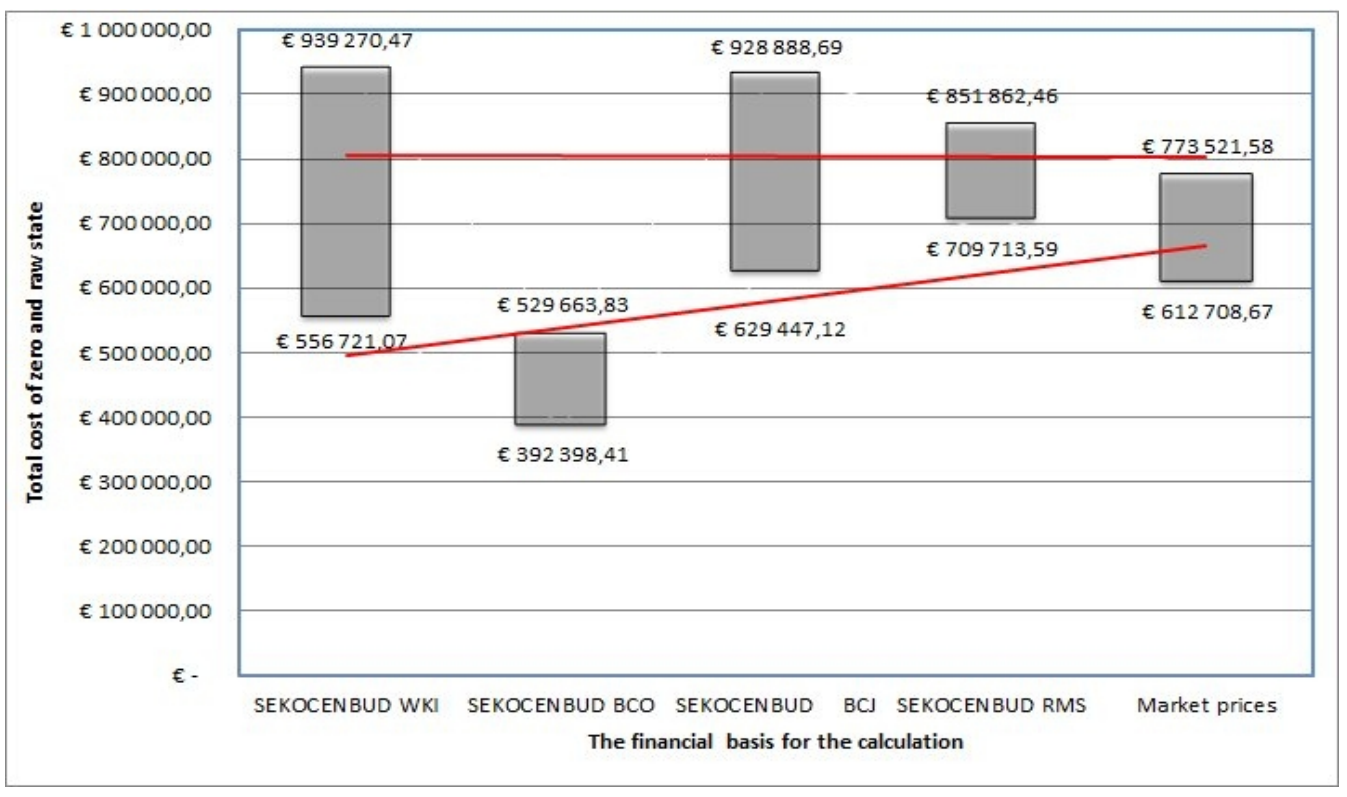

Figure 1. The planned costs of a multi-family 3-storey building in subsequent approximations

Source: own work

Figure 1 shows that the costs estimation process developed in Poland on the basis of the available pricing databases is far from optimal. Costs ranges marked on the chart show the limits which the expected project costs should not exceed according to calculations performed at different stages of project preparation. At the level of calculations based on structure prices bulletins (Sekocenbud BCO) a significant decrease of costs of the raw stage and building shell can be observed, which is below all the calculations resulting from the remaining estimates. Narrowing down the costs range in the subsequent approximations (stages) should be a logical continuation of the cost estimation process with an increasing amount of available information. The proper narrowing down of cost ranges is shown in the chart in accordance with the marked trend curves.

The last cost calculation - the tender cost estimate in the alternative scenario shows a decrease of the proposed labour prices due to the strong competitiveness observed at present in the building industry market in Poland. The prices reduced in the tender cost estimate result from the sub-contractors' acceptance of the proposed prices after negotiations, the prices of material manufacturers or wholesale prices, as well as taking into consideration the discounts on material purchase. Fig. 2 shows an excerpt of a report describing the most frequent reasons of contract delivery below the total value resulting from the client's estimate. 


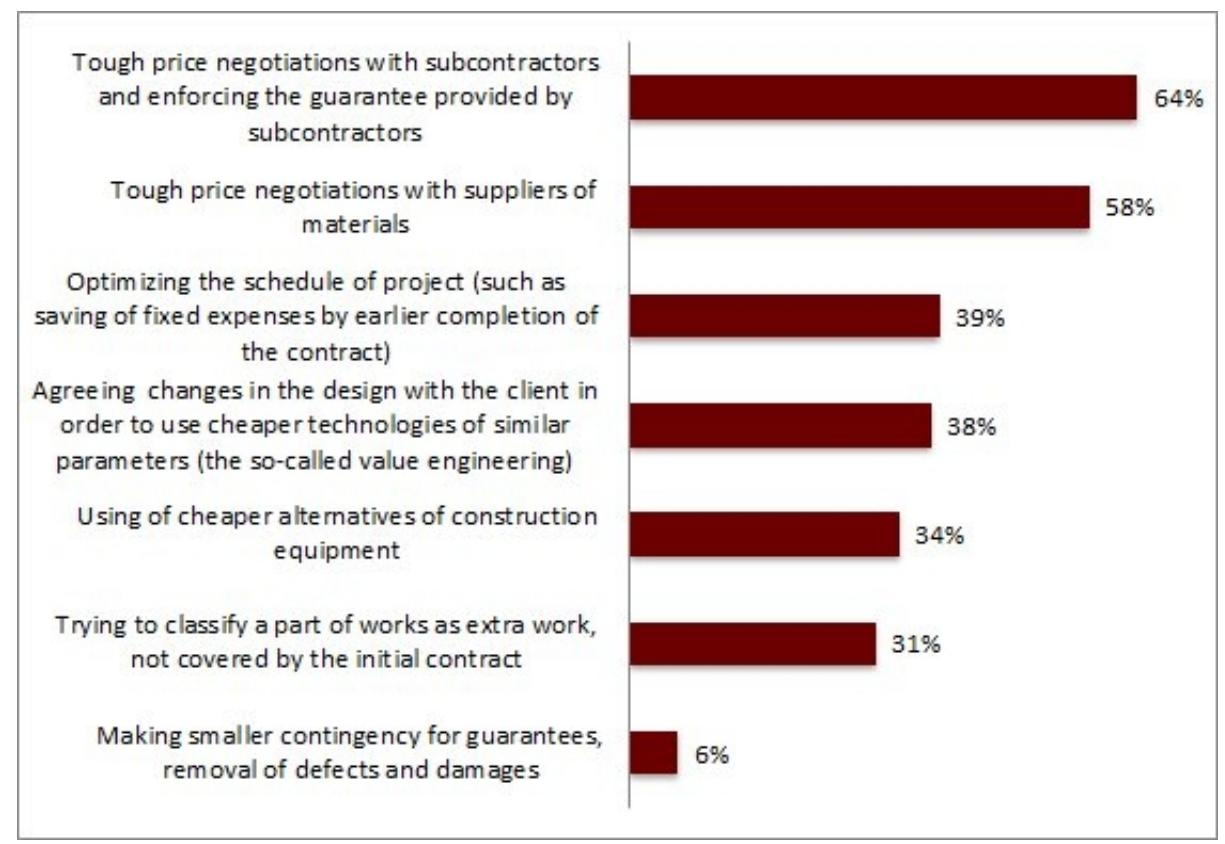

Figure 2. Actions taken by contractors to reduce the costs of building works ("Report", 2011)

A significant reduction of construction works prices entails a difficult market situation, the results of which are problems of many companies that cannot produce a profit or obtain contracts for construction works. In recent years in Poland many construction companies have gone bankrupt or the contractors have been abandoning building sites due to overly optimistic calculations connected with price reduction.

Moreover, Figure 3 and 4 show the trends in costs of the raw stage and building shell of the analysed structure. Along with the prices published by the Promocja - Sekocenbud Publishing House, the average prices published by Bistyp - Consulting Publishing House were also taken into consideration.

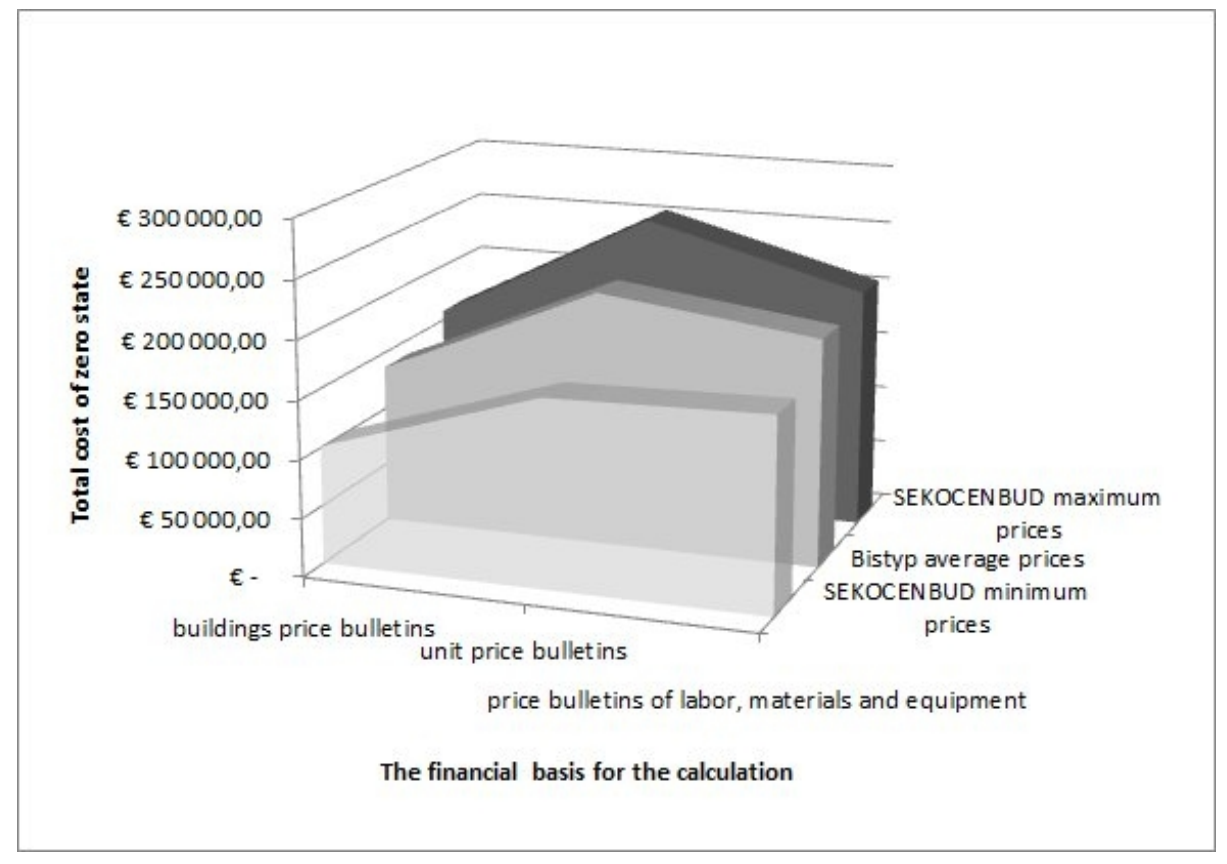

Figure 3. The costs of a multi-family 3 -storey building at the raw state according to various price bases 
Source: own work

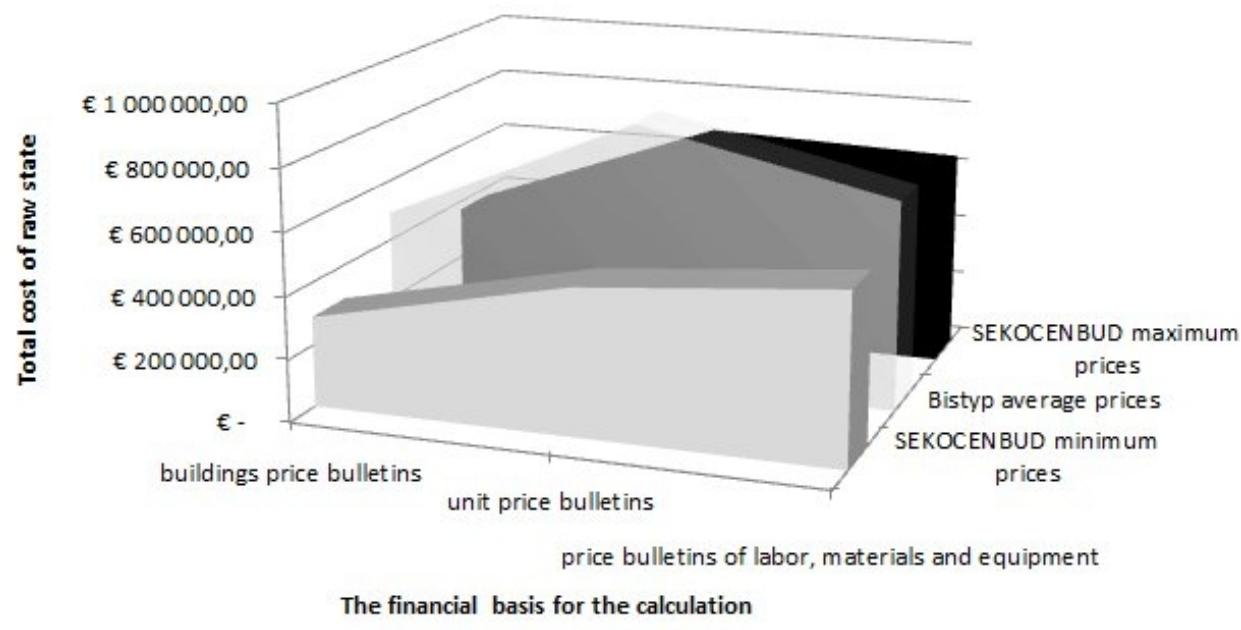

Figure 4 . The costs of a multi-family 3 -storey building at subsequent stages according to various price bases

Source: own work

While examining the raw stage and building shell costs separately, much greater discrepancies can be observed in the building shell calculations. In the case of the raw stage, the differences between the minimum and maximum prices in the following cost approximations tend to range from $24.4 \%$ to $56.2 \%$, while in the case of the building shell, from $23.5 \%$ to $81.6 \%$. Costs estimated at the price level taken from the RMS pricelists (Labour, Materials and Equipment) or market prices differ by approximately $20-30 \%$, both for the raw stage and the building shell. Considerably greater differences can be observed in the case of initial estimates: for the raw stage they range from $56.2 \%$ to $58.8 \%$, and for the building shell as much as from $69.3 \%$ to $81.6 \%$. It results from the differences in material prices - at the raw stage the material share in costs is relatively low.

\section{Reasons for Price Differences and Their Possible Reduction}

The price of a building is affected by many factors. The most frequently mentioned in Polish research include among others (Orłowski, 2010):

- soil conditions, on or under which a building will be founded,

- weather conditions that occur during performance of works,

- organization of work of contractor's management and on site,

- competence of workers and technical staff of the contractor,

- extension or reduction of the scheduled date of completion,

- the duration of warranty and quality assurance.

The specifics of construction of buildings results in inability to accurately predict a number of factors that affect the final cost. However, identification of factors that affect the cost variations at various stages of project performance can help to estimate them more accurately.

The main reasons for the differences in calculations at the conceptual stage and estimates at a tender stage in Poland are as follows:

- too long a period between a concept and execution and high price variability over time,

- insufficient amount of data and deficiencies in the design documentation,

- inability to predict the project determinants (e.g. soil and water conditions),

- inadequacy of price publications used in estimations.

The main reasons for the differences in a tender cost estimate and actual costs of the construction projects in Poland are as follows: 
- underestimation of the value of works at the bidding stage, resulting from the adoption of too low investment prices and unit prices of works,

- too little data in the tender design, errors in the design documentation and technical specification of implementation and delivery of works (Leśniak, Plebankiewicz, 2010)

- $\quad$ introduction of replacement works caused by variations in the tender design (error correction, change of solutions),

- a need to perform additional works caused by unforeseen circumstances or the client's decision,

- improvement of material and technological solutions presented in a design, often proposed by the contractor at the stage of construction works. Such action brings mutual benefits: cost savings and improved results of the contractor and reduction of project costs for the client, provided that it does not affect quality, usability, aesthetics and lifetime of the structure.

- $\quad$ extending time of completion against the schedule set at the bidding stage.

Cost analysis prepared by a client, leads to conclusion that in order to obtain the most reliable estimates, it seems important that the client:

- have an accurate and complete vision of a project and change it as little as possible during the construction, - proceed with tender procedures after the receipt of a completed interdisciplinary detailed design, including all accepted solutions and details, technical specifications for implementation and delivery of the works, all the arrangements with network operators'

- have a thorough Geology Engineering Report and a good recognition of soil conditions,

- have accurate information about the routes of existing networks and utilities.

In the case of tender calculations, the key factors affecting the accuracy of the estimate include:

- a detailed analysis of received tender documents and accepted design solutions,

- a detailed review of received Bill of Quantities and not relying solely on the Bill of Quantities received from the client,

- a thorough analysis of the bids received from contractors and relying on proven subcontractors, whose bids are reasonable and realistic,

- avoiding situations when the basis for establishing the contract price is exclusively a tender design, without technical specifications for implementation and delivery of works, with no detail and specific solutions.

\section{Summary and Conclusions}

Construction cost estimates are performed during the whole investment process. Subsequent stages provide more accurate data and allow for more and more complete analysis of the anticipated expenditures. At the project preparation stage, clients and contractors rely on price information available on the market. The paper shows that the data contained therein may not be accurate and may require a cautious approach. The results of the analyses conducted by the authors provide a conclusion that greater differences in subsequent stages of cost calculations occur in the raw state, where the main reason is a considerable variation in the material prices. In a building shell stage in turn, it is very difficult to predict the actual amount of earthworks.

Taking into account the specifics of construction projects, the differences between the forecast and actual costs are practically impossible to avoid in the construction industry. However, understanding the potential factors that may affect the cost variations as well as knowing the defects of the most popular pricing guides used by both clients and contractors, can improve the accuracy of calculations performed and help to predict the actual costs and prepare the necessary financial resources. From the perspective of both the client and the contractor it seems particularly important to carefully prepare the documentation, which is a source of information on the scope, amount and manner of performing the works and the proper selection of sources of price information.

\section{References}

Akintoye, A. (2000). Analysis of factors influencing project cost estimating. Construction Management and Economics, 18, 77-89. Retrieved from http://www.tandfonline.com/doi/abs/10.1080/014461900370979

Arafa, M., \& Alqedra, M. (2011). Early Stage Cost Estimation of Buildings Construction Projects using Artificial Neural Networks. Journal of Artificial Intelligence, 4, 63-75. Retrieved from http://scialert.net/abstract/?doi=jai.2011.63.75 
Ciraci, M., \& Polat, D. A. (2009). Accuracy levels of early cost estimates, in light of the estimate aims. Cost Engineering, 51(1), 16-24.

Dolecki, J. (2010). Tender price against the contractor's remuneration. Materials from the XV Częstochowa Conference, Częstochowa November, 111-124.

Dziadosz, A., \& Zima, K. (2011). The types of cost analyzes in the investment and construction process. The journal Świat Nieruchomości, 77, 51-56.

Hegazy, T., \& Ayed, A. (1998). Neural Network Model for Parametric Cost Estimation of Highway Projects. Journal of Construction Engineering and Management, 124(3), 210-218. Retrieved from http://ascelibrary.org/doi/abs/10.1061/(ASCE)0733-9364(1998)124:3(210)

Holm, L., Schaufelberger, J. E., Griffin, D., \& Cole, T. (2004). Construction Cost Estimating: Process and Practices (1st Ed.). Prentice Hall.

Ji, C., Hong, T., \& Hyun, C. (2010). CBR Revision Model for Improving Cost Prediction Accuracy in Multifamily Housing Projects. Journal of Management in Engineering, 26(4), 229-236. Retrieved from http://ascelibrary.org/doi/abs/10.1061/(ASCE)ME.1943-5479.0000018

Kim, G. H., Seo, D. S., \& Kang, K. I. (2005). Hybrid Models of Neural Networks and Genetic Algorithms for Predicting Preliminary Cost Estimates. Journal of Computing in Civil Engineering, 19(2), 208-211. http://ascelibrary.org/doi/abs/10.1061/(ASCE)0887-3801(2005)19:2(208)

Leśniak, A., \& Plebankiewicz, E. (2010). Errors in technical specification of implementation and delivery of works. Technical Journal, 1-B(2), 249-257.

Oberlender, G. D., \& Trost, S. M. (2001). Predicting accuracy of early cost estimates based on estimate quality, Journal of Construction Engineering and Management, 5, 173-182. Retrieved from http://ascelibrary.org/doi/abs/10.1061/(ASCE)0733-9364(2001)127:3(173)

Orłowski, H. J. (2010). Legal aspects of setting the price (remuneration) for construction works - cost estimate and lump sum remuneration. Materials from the scientific and technical conference in Ciechocinek, 55-79.

Peterson, S., \& Dagostino, F. R. (2011). Estimating in Building Construction (7th Ed.). Prentice Hall.

Petroutsatou, K., Georgopoulos, E., Lambropoulos, S., \& Pantouvakis, J. (2012). Early Cost Estimating of Road Tunnel Construction Using Neural Networks. Journal of Construction Engineering and Management, 138(6), 679-687. http://dx.doi.org/10.1061/(ASCE)CO.1943-7862.0000479

Plebankiewicz, E. (2007). Bases for cost estimation of building works - teaching support. Publisher PK, Cracow University of Technology.

Popescu, C., Ovararin, N., \& Phaobunjong, K. (2003). Estimating Building Costs. New York.

Van Kempen, J. R. (1983). Construction-Cost Estimating. Reston VA: Reston Publishing Co.

Zima, K. (2011). Price bases in cost estimations, Special supplement to the monthly journal "Builder”, 1, 44-49. 